Brazilian Journal

of Chemical

ISSN 0104-6632

Engineering

Printed in Brazil

Vol. 19, No. 03, pp. 267 - 275, July - September 2002

\title{
TREATMENT OF LOW-STRENGTH WASTEWATER USING IMMOBILIZED BIOMASS IN A SEQUENCING BATCH EXTERNAL LOOP REACTOR: INFLUENCE OF THE MEDIUM SUPERFICIAL VELOCITY ON THE STABILITY AND PERFORMANCE
}

\author{
E.F.M.Camargo ${ }^{1}$, S.M.Ratusznei ${ }^{1}$, J.A.D.Rodrigues ${ }^{1 *}$, M.Zaiat ${ }^{2}$ and W.Borzani ${ }^{1}$ \\ ${ }^{1}$ Departamento de Engenharia Química e de Alimentos, Escola de Engenharia Mauá, \\ Centro Universitário, Instituto Mauá de Tecnologia (IMT), Praça Mauá 1, \\ CEP 09.580-900, Fax +55 114239 3131, São Caetano do Sul - SP. Brasil. \\ E-mail: rodrigues@maua.br; \\ ${ }^{2}$ Departamento de Hidráulica e Saneamento, Escola de Engenharia de São Carlos, \\ Universidade de São Paulo (USP), Av. Trabalhador São-Carlense 400, \\ CEP 13.566-590, São Carlos - SP, Brasil.
}

(Received:October 1, 2001; Accepted:June 10, 2002)

\begin{abstract}
An anaerobic sequencing batch bioreactor with external circulation of the liquid phase wherein the biomass was immobilized on a polyurethane foam matrix was analyzed, focussing on the influence of the liquid superficial velocity on the reactor's stability and efficiency. Eight-hour cycles were carried out at $30^{\circ} \mathrm{C}$ treating glucose-based synthetic wastewater around $500 \mathrm{mgDQO} / \mathrm{L}$. The performance of the reactor was assessed without circulation and with circulating liquid superficial velocity between 0.034 and $0.188 \mathrm{~cm} / \mathrm{s}$. The reactor attained operating stability and a high organic matter removal was achieved when liquid was circulated. A first order model was used to evaluate the influence of the liquid superficial velocity $\left(v_{S}\right)$, resulting in an increase in the apparent first order parameter when $\mathrm{v}_{\mathrm{S}}$ increased from 0.034 to $0.094 \mathrm{~cm} / \mathrm{s}$. The parameter value remained unchangeable when $0.188 \mathrm{~cm} / \mathrm{s}$ was applied, indicating that beyond this value no improvement on liquid mass transfer was observed. Moreover, the necessary time to reach the final removal efficiency decreased when liquid circulation was applied, indicating that a 3-hour cycle could be enough.

Keywords: anaerobic sequencing batch reactor; immobilized biomass; liquid external circulation; polyurethane foam.
\end{abstract}

\section{INTRODUCTION}

Anaerobic sequencing batch reactors (ASBR) have been widely studied for wastewater treatment due to some advantages as good solids retention, elimination of the secondary sedimentation step, efficient operating control, relatively high organic matter removal efficiency and simple operation.
Moreover, it could be used to treat some wastewater discharged in an intermittent way (Zaiat et al., 2001). Ndon \& Dague (1997a, 1997b) and Brito et al. (1997) indicate that the anaerobic sequencing batch reactors are a good alternative of lower-cost treatment of low-strength industrial and municipal wastewater.

The ASBR operation is composed of four steps:

*To whom correspondence should be addressed 
feed, reaction, settling and liquid withdrawal (Dague et al., 1992). During the reaction step some kind of mixture should guarantee an effective contact between de biomass and the bulk liquid in order to improve the overall organic matter uptake rates. The necessary mixing can be provided by circulation of the biogas produced (Sung \& Dague, 1995). However, for low strength wastewater the biogas production is insufficient and an alternative mixing may be necessary (Brito et al., 1997). Circulation of the bulk liquid through a pump (Hirl \& Irvine, 1996; Brito et al., 1997) or mechanical agitation (Ratusznei et al., 2000) can also be used.

The biomass settling, necessary to assure sedimentation of the biomass providing the solids removal efficiency, may be the determining step of the cycle time since it is directly related to the formation of self-immobilized biomass as granules with good settleability. However, present knowledge of the self-immobilization process is not sufficient to guarantee its occurrence and control (Zaiat et al., 1997a). Hence, immobilization of biomass in inert supports is useful to provide biomass retention even under adverse operating conditions. Ratusznei et al. (2000) used anaerobic biomass immobilized in polyurethane foam to treat domestic synthetic wastewater in a stirred ASBR, achieving high organic matter removal efficiency and high solids retention, eliminating the settling step.

However, utilization of immobilized biomass on inert support introduces internal and external mass transfer resistances from the liquid bulk phase to the anaerobic biomass aggregates that can reduce the organic matter uptake rates, worsening the performance of the reactor. In this way implementation of mixing in the reactor becomes very important since the overall mass transfer rates can be increased and the ASBR operation improved.

This work investigates an anaerobic sequencing batch reactor configuration with an external liquid circulation system and immobilized biomass on an inert support, treating a low strength glucose-based synthetic wastewater. The influence of the superficial velocity on the reactor's performance was evaluated through utilization of different circulating flow rates.

\section{MATERIAL AND METHODS}

The anaerobic bioreactor with external circulation of the liquid phase is shown in Figure 1. The reactor consists of a cylindrical flask with an external diameter of $60 \mathrm{~mm}, 460 \mathrm{~mm}$ of height and $3.5 \mathrm{~mm}$ of wall thickness, resulting approximately in a work volume of $1.0 \mathrm{~L}$. The fixed-bed with $410 \mathrm{~mm}$ of height, composed of 5-mm cubic polyurethane foam matrices (apparent density of $23 \mathrm{~kg} / \mathrm{m}^{3}$ ) containing the immobilized biomass and confined between two punctured stainless steel disks, resulting in a bed porosity of $40 \%$ (Zaiat et al., 1997b). The reactor was inoculated with granular anaerobic sludge with $54 \mathrm{mg}$-tvs/g-sludge taken from an UASB reactor treating poultry slaughterhouse wastewater. The sludge was immobilized on $20 \mathrm{~g}$ of foam as described by Zaiat et al. (1994), attaining solid concentrations of $0.66 \mathrm{~g}$-ts $/ \mathrm{g}$-foam and $0.53 \mathrm{~g}$-tvs $/ \mathrm{g}$ foam, thus resulting in an initial volatile solids content $(\mathrm{X})$ of $10.6 \mathrm{~g}$ in the reactor volume.

The liquid phase circulating system was composed of an adjustable peristaltic flow pump and a reservoir with $40 \mathrm{~mm}$ of external diameter, 200 $\mathrm{mm}$ of height, $3.3 \mathrm{~mm}$ of wall thickness, with a volume about $0.2 \mathrm{~L}$. Thus, the total reactor volume was $1.2 \mathrm{~L}$.

Batch cycles of eight hours were carried out at a temperature of $30 \pm 1^{\circ} \mathrm{C}$, treating approximately 500 $\mathrm{mL}$ of a glucose-based synthetic wastewater with approximately $500 \mathrm{mg} \mathrm{COD} / \mathrm{L}$, prepared with glucose $(500 \mathrm{mg} / \mathrm{L})$, urea $(125 \mathrm{mg} / \mathrm{L}), \mathrm{NiSO}_{4} \cdot 6 \mathrm{H}_{2} \mathrm{O}$ $(1 \mathrm{mg} / \mathrm{L}), \mathrm{FeSO}_{4} \cdot 7 \mathrm{H}_{2} \mathrm{O}(5 \mathrm{mg} / \mathrm{L}), \mathrm{FeCl}_{3} \cdot 6 \mathrm{H}_{2} \mathrm{O}(0.5$ $\mathrm{mg} / \mathrm{L}), \mathrm{CaCl}_{2} \cdot \mathrm{H}_{2} \mathrm{O}(47 \mathrm{mg} / \mathrm{L}), \mathrm{CoCl}_{2} \cdot 6 \mathrm{H}_{2} \mathrm{O} \quad(0.08$ $\mathrm{mg} / \mathrm{L}), \mathrm{Na}_{2} \mathrm{SeO}_{3}(0.07 \mathrm{mg} / \mathrm{L}), \mathrm{KH}_{2} \mathrm{PO}_{4}(85 \mathrm{mg} / \mathrm{L})$, $\mathrm{K}_{2} \mathrm{HPO}_{4} \quad(22 \mathrm{mg} / \mathrm{L}), \mathrm{Na}_{2} \mathrm{HPO}_{4} \quad(33 \mathrm{mg} / \mathrm{L})$ and $\mathrm{NaHCO}_{3}(500 \mathrm{mg} / \mathrm{L})$.

The reactor operation without and with liquid circulation was composed of three steps: feed (5 $\mathrm{min}$ ), reaction (470 $\mathrm{min}$ ) and liquid withdrawal (5 min), since the settling step was eliminated due to the presence of immobilized biomass. Both feed and liquid withdraw steps were performed by an adjustable peristaltic flow pump. Moreover, during these two steps the circulation pump was turned off. The liquid flow rates used were $1.1,3.0$ and $6 \mathrm{~L} / \mathrm{h}$, resulting in liquid superficial velocities of 0.034 , 0.054 and $0.188 \mathrm{~cm} / \mathrm{s}$, respectively. These values were based on the results obtained by Zaiat et al. $(1997 a, b)$ studying the influence of superficial velocities on the solids retention in the same inert support. The early velocities were calculated by Equation (1), where $\mathrm{Q}$ is the liquid circulation flow rate, $\mathrm{A}$ is the internal cross-sectional area of the reactor and $\varphi$ is the fixed-bed porosity. Each test took at least 20 days ( 60 cycles).

$$
\mathrm{v}_{\mathrm{S}}=\frac{\mathrm{Q}}{\varphi \mathrm{A}}
$$


The chemical oxygen demand (COD), total volatile acid (TVA), bicarbonate alkalinity (BA), total solids (TS), total volatile solids (TVS), total suspended solids (TSS), volatile suspended solids (VSS) and $\mathrm{pH}$ were monitored in both the influent and effluent in different cycles for all conditions according to Standard Methods for the Examination of Water and Wastewater (1995) procedures. The biogas composition was evaluated through gas chromatography. The discharged volume in each batch test was also monitored.

The reactor's performance was evaluated by the overall substrate removal efficiencies based on nonfiltered andfilteredsamples $\varepsilon_{S} \quad$ Theseparameters were calculated by Equations (2) and (3), respectively, where $C_{I}$ is the influent non-filtered substrate concentration, $\mathrm{C}_{\mathrm{ET}}$ is the effluent nonfiltered substrate concentration, $\mathrm{C}_{\mathrm{ES}}$ is the effluent filtered substrate concentration.

$\varepsilon_{\mathrm{T}}=\frac{\mathrm{C}_{\mathrm{I}}-\mathrm{C}_{\mathrm{ET}}}{\mathrm{C}_{\mathrm{I}}}$

$\varepsilon_{\mathrm{S}}=\frac{\mathrm{C}_{\mathrm{I}}-\mathrm{C}_{\mathrm{ES}}}{\mathrm{C}_{\mathrm{I}}}$

The organic volumetric loading (OVL), the specific organic loading (SOL) and the specific organic removal (SOR) were calculated by Equations (4), (5) and (6), respectively, where $V_{\text {dfed }}$ was the daily treated influent volume, $V_{\text {fed }}$ was the influent volume treated per cycle and $V_{\text {reactor }}$ was the total volume of the reactor. Moreover, the anaerobic biomass amount (X) was admitted as constant during the assays.

$\mathrm{OVL}=\frac{\mathrm{V}_{\text {dfed }} \mathrm{C}_{\mathrm{I}}}{\mathrm{V}_{\text {reactor }}}$

$\mathrm{SOL}=\frac{\mathrm{OVL} \mathrm{V}_{\text {reactor }}}{\mathrm{X}}$

$\mathrm{SOR}=\frac{\mathrm{V}_{\text {fed }}\left(\mathrm{C}_{\mathrm{I}}-\mathrm{C}_{\mathrm{ES}}\right)}{\mathrm{X}}$

In order to examine the influence of superficial velocity on the reactor's performance, the filtered substrate concentration in the reactor profiles along the cycle i), calculated by Equation (7), was measured when the reactor was operated on a stable condition, i.e., when the filtered substrate, bicarbonate alkalinity and total volatile acids effluent concentrations presented no significant variation from one cycle to another. In Equation (7), $\mathrm{C}_{\mathrm{S}}$ is the filtered substrate concentration in the reactor and $\mathrm{C}_{\mathrm{So}}$ the initial value of $\mathrm{C}_{\mathrm{S}}$.

$\varepsilon_{\mathrm{i}}=\frac{\mathrm{C}_{\mathrm{So}}-\mathrm{C}_{\mathrm{S}}}{\mathrm{C}_{\mathrm{So}}}$

To obtain the filtered substrate concentration-time profile in the reactor for the condition without liquid circulation, the medium was homogenized just before the sample withdrawal in order to assure the measurement of the actual average concentration of the substrate in the reactor. For this reason, the following procedure was adopted. In a given cycle, at a certain time $t_{1}$, the medium was discharged, homogenized and then the sample was taken, leading to the first point of the profile. After completion of the above cycle, three consecutive undisturbed cycles were run with the purpose to eliminate the disturbance produced by the cited discharge. Then, during the next cycle, at time $t_{2}>t_{1}$, the second sample was taken as described above leading to the second point of the profile. The above operation was repeated in order to obtain the entire profile. When the assays were carried out with liquid circulation, the filtered substrate concentration in the reactor profile was obtained in a single cycle, in which the samples were taken from the reservoir using a syringe.

Mathematical analysis of the influence of the superficial velocity on the reactor's dynamic efficiency was performed by non-linear fitting of the first order kinetic model to the transient profiles of filtered substrate concentration in the reactor $\left(\mathrm{C}_{\mathrm{S}}\right)$ during the cycle, shown in Equation (9) obtained from the material balance shown in Equation (8) and the initial condition (Equation 8-a), using the LevenbergMarquardt numerical method. The parameter $\mathrm{k}_{1}{ }^{\text {app }}$ stands for the apparent kinetic coefficient, as it embodies the intrinsic kinetic constant as well as the internal and external mass transfer resistances while the residual concentration $\left(\mathrm{C}_{\mathrm{SR}}\right)$ represents the value of filtered substrate concentration in the reactor when the value of the reaction rate (Rs) was zero.

$$
\begin{aligned}
& -\frac{\mathrm{dC}_{\mathrm{S}}}{\mathrm{dt}}=\mu_{\mathrm{S}} \mathrm{C}_{\mathrm{X}}=\mathrm{R}_{\mathrm{S}}=\mathrm{k}_{1}{ }^{\text {app }}\left(\mathrm{C}_{\mathrm{S}}-\mathrm{C}_{\mathrm{SR}}\right) \\
& \mathrm{t}=0 \Rightarrow \mathrm{C}_{\mathrm{S}}=\mathrm{C}_{\mathrm{So}} \\
& \mathrm{C}_{\mathrm{S}}=\mathrm{C}_{\mathrm{SR}}+\left(\mathrm{C}_{\mathrm{So}}-\mathrm{C}_{\mathrm{SR}}\right) \exp \left(-\mathrm{k}_{1} \mathrm{t}\right)
\end{aligned}
$$




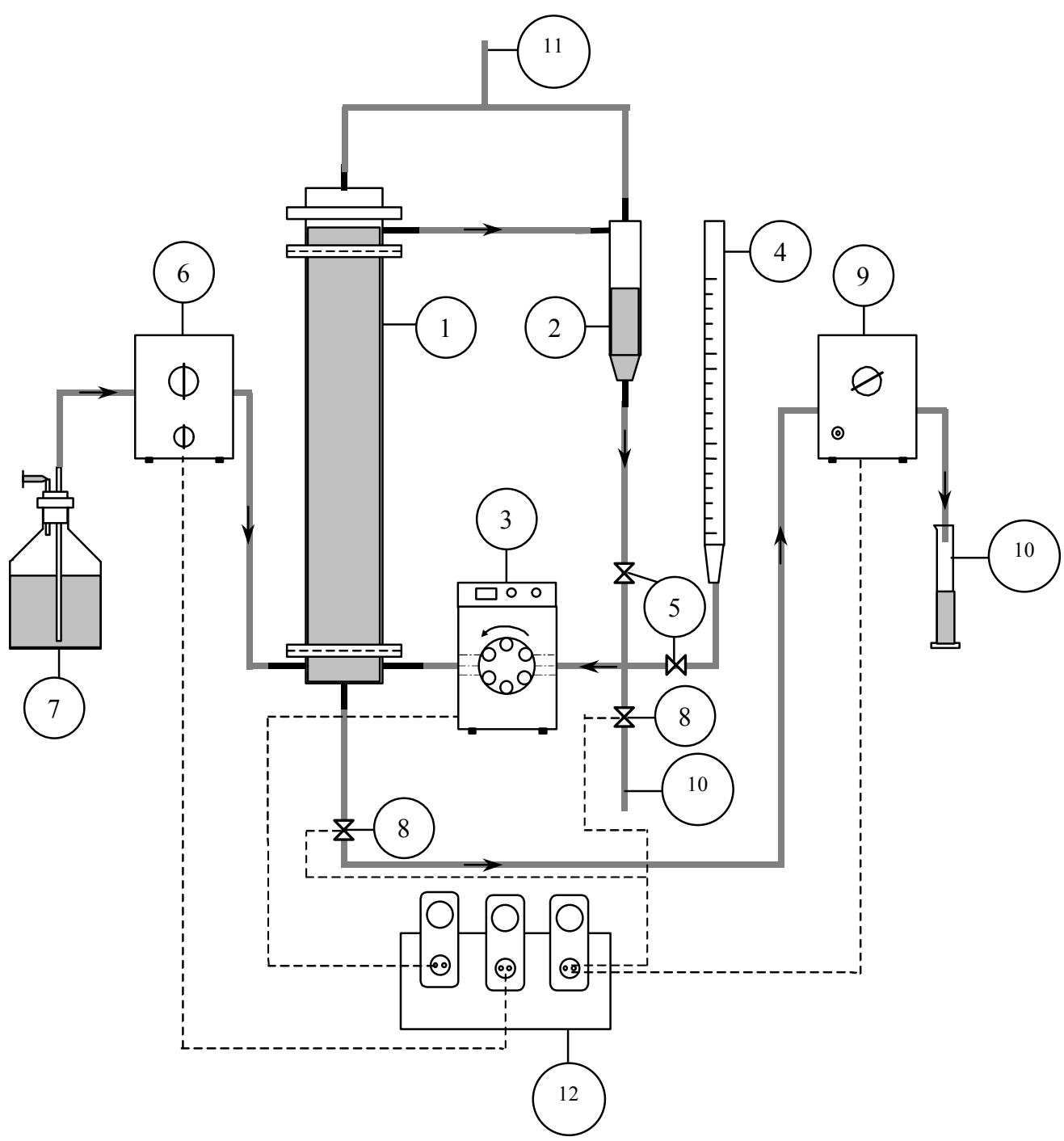

Figure 1: Scheme of the anaerobic sequencing batch reactor with external circulation of the liquid phase and immobilized biomass: 1) reactor containing immobilized biomass; 2) external reservoir; 3) circulation pump; 4) flow rate meter; 5) valves; 6) feed pump; 7) synthetic wastewater reservoir; 8) discharge valve; 9) discharge pump; 10) effluent outlet; 11) biogas outlet; 12) control unit; - hydraulic connections; ---- electric connections.

\section{RESULTS AND DISCUSSION}

The mean values and the respective standard errors of the main monitored variables in the reactor in both influent and effluent are shown in Tables 1,2 and 3. The low standard deviations observed in effluent samples (Table 1) indicate that reactor operation was sufficiently stable. The $\mathrm{pH}$ values, the low values of total volatile acids concentration, the generation of bicarbonate alkalinity in the effluent and the biogas composition confirm a stable methanogenic process in the reactor (Table 2). The influent and effluent values of solids (Table 3) indicate that washout was not effective during the experimental period since the polyurethane foam matrices provided suitable condition for biomass retention even when the highest superficial velocity was applied. 
The value of $\mathrm{V}_{\text {fed }}$ shown in Table 1 was lower for the no circulation condition due to the extra volume needed to perform circulation, i.e., the volume needed for circulation of the flow pump. In Table 2, the methane content in the first experiment is higher probably due to the higher loss of biogas when circulation was implemented. Moreover, the values obtained for TSS and VSS are very low, perhaps meaningless, however, these values are important to show the quality of the effluent in a process without settling step.

A relatively high efficiency was achieved for all studied conditions (Table 1). The results indicated the improvement from $83 \%$ to $95 \%$ for the nonfiltered substrate COD removal efficiency $\left(\varepsilon_{\mathrm{T}}\right)$, when circulation was implemented. However no significant enhancement in the efficiency was observed as the liquid superficial velocity was increased due to the extended cycle time ( 8 hours).

The organic volumetric loading in the reactor was $498 \mathrm{mg}$ COD/L.d, the specific organic loading was $56.4 \mathrm{mg}$ COD/g-tvs.d and the specific organic removals were $15.7 \mathrm{mg} \mathrm{COD} / \mathrm{g}$-tvs.L and 17.7 $\mathrm{mgCOD} / \mathrm{g}$-tvs.L, respectively, for the conditions without and with circulation. The values of total reactor volume, average treated volume per cycle, biomass content in the reactor, average non-filtered influent substrate concentration and average nonfiltered effluent substrate concentration without and with circulation were $1.2 \mathrm{~L}, 380 \mathrm{~mL}, 10.6$ g-tvs, 525 $\mathrm{mg} \mathrm{COD} / \mathrm{L}, 87 \mathrm{mgCOD} / \mathrm{L}$ and $32 \mathrm{mgCOD} / \mathrm{L}$, respectively. These are low values but typical for low-strength wastewater.

In order to verify how the organic matter removal took place, the filtered substrate profiles along a cycle time were taken for all studied conditions, evaluating the influence of superficial velocity on the dynamic efficiency of the reactor, when non-filtered and filtered effluent substrate concentration presented no significant variation from one cycle to another. Figures 2 to 5 show the experimental and fitted values of the conversion and organic material removal rate profiles during a batch cycle for all studied conditions.

The results shown in Table 4 are divided in two groups: (a) without circulation, of which the mass transfer is based on diffusion phenomenon (the value of $\mathrm{C}_{\mathrm{SR}}$ is higher than the others) and (b) with circulation, of which the mass transfer is based on convection phenomenon. Therefore, the dependence of the apparent kinetic parameter on the superficial velocity should be taken into account only for the conditions for which circulation was implemented.

The influence of the liquid superficial velocity on the behavior of the dynamic substrate concentration profile can be assessed through the variation of apparent kinetic coefficient $\left(\mathrm{k}_{1}{ }^{\mathrm{app}}\right)$ values (Table 4$)$, which is directly related to the liquid-phase mass transfer coefficient. An increase in the apparent first order parameter was observed when the liquid superficial velocity increased from 0.034 to 0.094 $\mathrm{cm} / \mathrm{s}$, remained unchangeable when the superficial velocity was increased to $0.188 \mathrm{~cm} / \mathrm{s}$. This indicates an effective influence of the liquid-phase mass transfer on the overall reaction rate and, consequently, on the overall performance of the process, indicating that the improvement due to the convection effects attain a limit level. Furthermore, these results suggest that the increase in the liquid superficial velocity decreased the time required to reach the final removal efficiency since the organic matter removal rate only presented significant values for the first three hours of the operation cycle. These results suggest that the cycle time can be reduced as the liquid superficial velocity is increased, thus permitting optimization of the performance of the reactor.

Table 1: Mean values of substrate concentrations, efficiency and effluent volume monitored in the reactor operated at different superficial velocities.

\begin{tabular}{|c|c|c|c|c|c|c|c|}
\hline \multirow{2}{*}{$\begin{array}{c}\mathrm{v}_{\mathrm{S}} \\
\left(10^{-2} \mathrm{~cm} / \mathrm{s}\right)\end{array}$} & \multirow{2}{*}{$\begin{array}{c}\mathbf{Q} \\
(\mathrm{L} / \mathrm{h})\end{array}$} & \multirow{2}{*}{$\mathrm{C}_{\mathrm{I}}(\mathrm{mgCOD} / \mathrm{L})$} & \multicolumn{2}{|c|}{$\mathrm{C}_{\mathrm{E}}(\mathrm{mgCOD} / \mathrm{L})$} & \multicolumn{2}{|c|}{$\varepsilon(\%)$} & \multirow{2}{*}{$\mathbf{V}_{\text {fed }}(\mathbf{m L})$} \\
\hline & & & $\mathrm{C}_{\mathrm{ET}}$ & $\mathrm{C}_{\mathrm{ES}}$ & $\varepsilon_{\mathrm{T}}$ & $\varepsilon_{\mathrm{S}}$ & \\
\hline 0 & 0 & $522 \pm 9$ & $87 \pm 18$ & $75 \pm 16$ & $83 \pm 3$ & $86 \pm 3$ & $271 \pm 23$ \\
\hline $3.4 \pm 0.2$ & $1.1 \pm 0.1$ & $518 \pm 21$ & $25 \pm 2$ & $22 \pm 2$ & $95 \pm 1$ & $96 \pm 1$ & $346 \pm 8$ \\
\hline $9.4 \pm 0.2$ & $3.0 \pm 0.1$ & $521 \pm 8$ & $35 \pm 24$ & $23 \pm 14$ & $95 \pm 5$ & $96 \pm 3$ & $441 \pm 24$ \\
\hline $18.8 \pm 0.6$ & $6.0 \pm 0.2$ & $537 \pm 8$ & $36 \pm 3$ & $25 \pm 5$ & $93 \pm 1$ & $95 \pm 1$ & $462 \pm 9$ \\
\hline
\end{tabular}


Table 2: Mean values of bicarbonate alkalinity, total volatile acids and pH monitored in the reactor operated at different superficial velocities.

\begin{tabular}{|c|c|c|c|c|c|c|c|c|}
\hline \multirow[t]{2}{*}{$\begin{array}{c}v_{S} \\
\left(10^{-2} \mathrm{~cm} / \mathrm{s}\right)\end{array}$} & \multicolumn{2}{|c|}{$\begin{array}{c}\mathrm{BA} \\
\left(\mathrm{mgCaCO}_{3} / \mathrm{L}\right)\end{array}$} & \multicolumn{2}{|c|}{$\begin{array}{c}\text { TVA } \\
(\mathrm{mgHAc} / \mathrm{L})\end{array}$} & \multicolumn{2}{|c|}{ pH } & \multicolumn{2}{|c|}{ Biogas Composition (\%) } \\
\hline & Influent & Effluent & Influent & Effluent & Influent & Effluent & $\mathrm{CH}_{4}$ & $\mathrm{CO}_{2}$ \\
\hline 0 & $283 \pm 10$ & $372 \pm 34$ & $46 \pm 8$ & $74 \pm 21$ & $7.4 \pm 0.1$ & $6.7 \pm 0.2$ & $63 \pm 12$ & $37 \pm 12$ \\
\hline $3.4 \pm 0.2$ & $285 \pm 14$ & $375 \pm 18$ & $47 \pm 8$ & $45 \pm 14$ & $7.7 \pm 0.1$ & $7.3 \pm 0.1$ & $52 \pm 4$ & $48 \pm 4$ \\
\hline $9.4 \pm 0.2$ & $295 \pm 8$ & $390 \pm 10$ & $47 \pm 4$ & $53 \pm 6$ & $7.7 \pm 0.1$ & $7.1 \pm 0.1$ & $51 \pm 4$ & $49 \pm 4$ \\
\hline $18.8 \pm 0.6$ & $292 \pm 24$ & $370 \pm 13$ & $51 \pm 5$ & $62 \pm 10$ & $7.6 \pm 0.1$ & $7.0 \pm 0.1$ & $52 \pm 3$ & $48 \pm 3$ \\
\hline
\end{tabular}

Table 3: Mean values of total and suspended solids concentration monitored in the reactor operated at different superficial velocities.

\begin{tabular}{|c|c|c|c|c|c|c|c|c|}
\hline $\begin{array}{c}v_{\text {S }} \\
\left(10^{-2} \mathbf{c m} / \mathbf{s}\right)\end{array}$ & \multicolumn{2}{|c|}{ TS (mg/L) } & \multicolumn{2}{c|}{ TVS (mg/L) } & \multicolumn{2}{c|}{ TSS (mg/L) } & \multicolumn{2}{c|}{ VSS (mg/L) } \\
\hline \multirow{3}{*}{0} & Influent & Effluent & Influent & Effluent & Influent & Effluent & Influent & Effluent \\
\cline { 2 - 9 } & $1092 \pm 83$ & $731 \pm 90$ & $727 \pm 97$ & $353 \pm 81$ & $30 \pm 13$ & $31 \pm 9$ & $15 \pm 7$ & $18 \pm 7$ \\
$3.4 \pm 0.2$ & $1096 \pm 29$ & $687 \pm 37$ & $707 \pm 42$ & $284 \pm 23$ & $33 \pm 15$ & $30 \pm 18$ & $8 \pm 5$ & $14 \pm 6$ \\
$9.4 \pm 0.2$ & $1011 \pm 119$ & $728 \pm 28$ & $636 \pm 82$ & $339 \pm 34$ & $51 \pm 2$ & $41 \pm 21$ & $22 \pm 13$ & $18 \pm 18$ \\
$18.8 \pm 0.6$ & $1036 \pm 63$ & $713 \pm 115$ & $692 \pm 85$ & $438 \pm 47$ & $41 \pm 14$ & $48 \pm 21$ & $20 \pm 15$ & $24 \pm 17$ \\
\hline
\end{tabular}

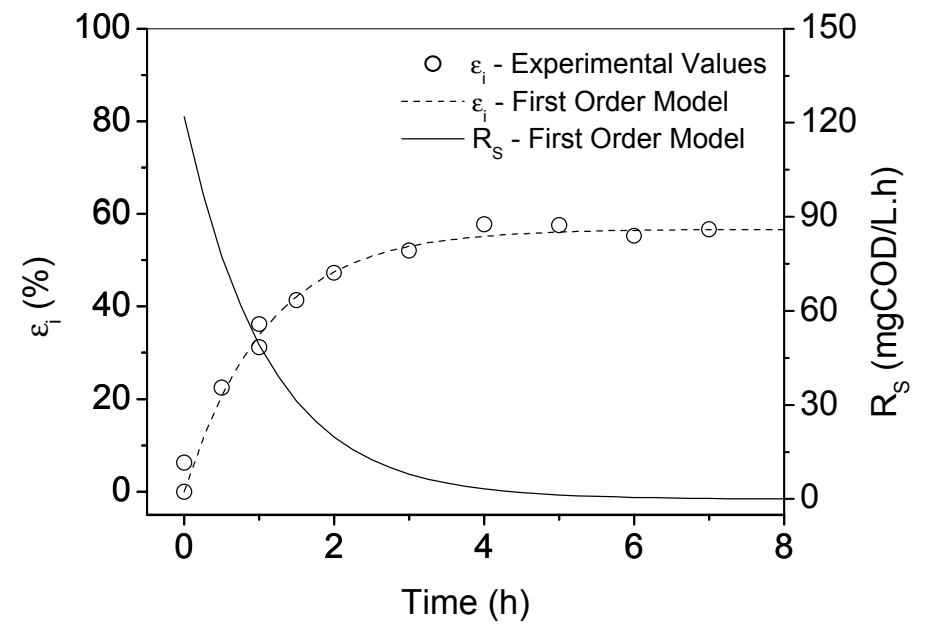

Figure 2: Experimental and fitted values of the conversion and organic material removal rate profiles during a batch cycle for the condition without liquid circulation. 


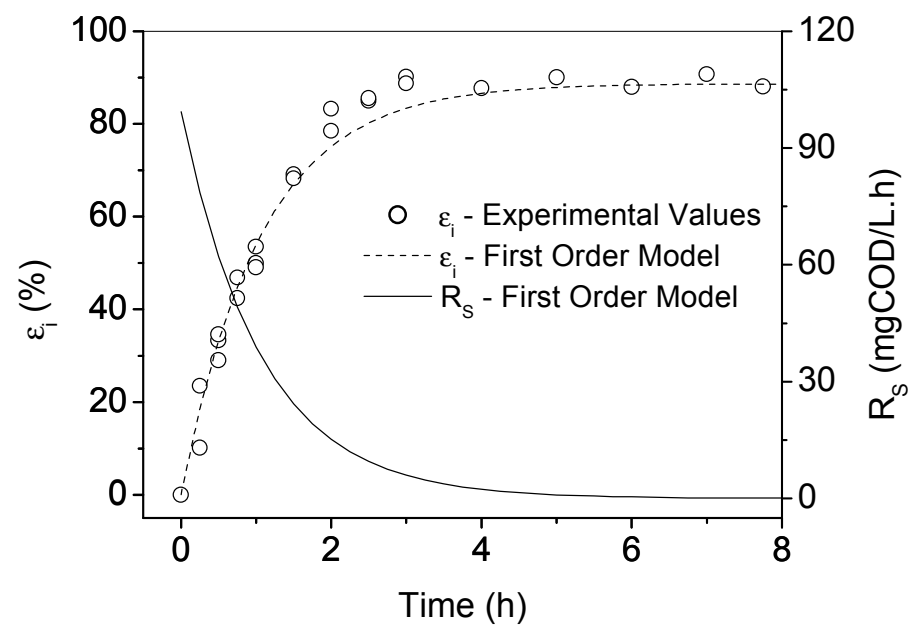

Figure 3: Experimental and fitted values of the conversion and organic material removal rate profiles during a batch cycle for the condition with superficial velocity of $0.034 \mathrm{~cm} / \mathrm{s}$.

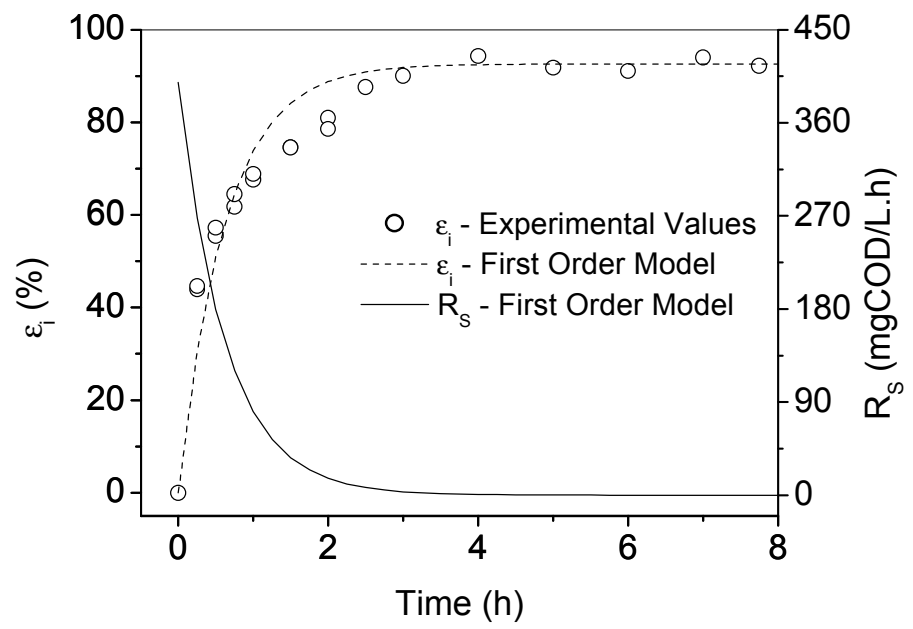

Figure 4: Experimental and fitted values of the conversion and organic material removal rate profiles during a batch cycle for the condition with superficial velocity of $0.094 \mathrm{~cm} / \mathrm{s}$.

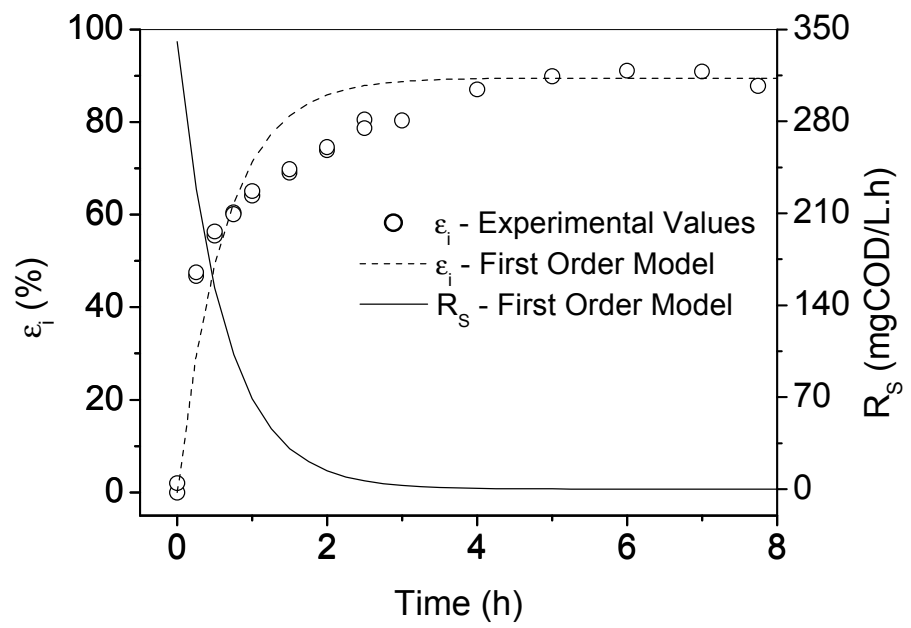

Figure 5: Experimental and fitted values of the conversion and organic material removal rate profiles during a batch cycle for the condition with superficial velocity of $0.188 \mathrm{~cm} / \mathrm{s}$. 
Table 4: Values of apparent kinetic parameter, residual substrate concentration and determination coefficient $\left(r^{2}\right)$.

\begin{tabular}{|c|c|c|c|}
\hline $\mathbf{v}_{\mathbf{S}}\left(\mathbf{1 0}^{-\mathbf{2}} \mathbf{~ \mathbf { m }} / \mathbf{s}\right)$ & $\left.\mathbf{k}_{\mathbf{1}}{ }^{\text {app }} \mathbf{( h}^{\mathbf{- 1}}\right)$ & $\mathbf{C}_{\mathbf{S R}}(\mathbf{m g} / \mathbf{L})$ & $\mathbf{r}^{\mathbf{2}}$ \\
\hline 0 & $0.91 \pm 0.06$ & $102 \pm 3$ & 0.979 \\
$3.4 \pm 0.2$ & $0.94 \pm 0.04$ & $13 \pm 1$ & 0.980 \\
$9.4 \pm 0.2$ & $1.6 \pm 0.1$ & $20 \pm 4$ & 0.950 \\
$18.8 \pm 0.6$ & $1.6 \pm 0.1$ & $25 \pm 4$ & 0.903 \\
\hline
\end{tabular}

\section{CONCLUSIONS}

The results obtained in this work permitted to conclude about the enhancement performance in an anaerobic sequencing batch reactor with immobilized biomass due to implementation of the external liquid circulation, which improves the liquid mass transfer from the liquid bulk phase to immobilized biomass. Furthermore, the inert support of polyurethane foam was very adequate, since it guaranteed suitable solid retention even at high liquid superficial velocity, thus permitting the suppression of the settle step in ASBR operation.

The organic matter removal efficiency increased from $83 \%$ to $95 \%$ for the non-filtered substrate COD removal efficiency when the liquid circulation was implemented as a consequence of the better contact between biomass and substrate, thus improving the overall organic matter uptake rate.

The kinetic study revealed that the value of the first-order apparent kinetic coefficient was approximately duplicated when the liquid superficial velocity was increased from 0.034 to $0.094 \mathrm{~cm} / \mathrm{s}$. Such a parameter remained unchangeable for the highest value of $0.188 \mathrm{~cm} / \mathrm{s}$. This result shows the possibility of minimizing of the time required to obtain the final removal efficiency through implementation of external liquid circulation.

\section{ACKNOWLEDGMENTS}

This study was supported by the Fundação de Amparo à Pesquisa do Estado de São Paulo FAPESP (São Paulo, Brasil), process numbers 97/05.987-3 and 97/13.270-1 (J.A.D. Rodrigues), 98/10.303-9 (S.M. Ratusznei) and 98/07.131-1 (E.M.F. Camargo).

NOMENCLATURE
A

BA

$\mathrm{C}_{\mathrm{ES}}$

$\mathrm{C}_{\mathrm{ET}}$

$\mathrm{C}_{\mathrm{I}}$

$\mathrm{C}_{\mathrm{S}}$ filtered substrate concentration in the reactor, $\mathrm{mgCOD} / \mathrm{L}$

$\mathrm{C}_{\mathrm{So}} \quad$ initial value of $\mathrm{C}_{\mathrm{S}}, \mathrm{mgCOD} / \mathrm{L}$

$\mathrm{C}_{\mathrm{SR}} \quad$ residual filtered substrate concentration in the reactor, $\mathrm{mgCOD} / \mathrm{L}$

$\mathrm{C}_{\mathrm{X}} \quad$ biomass concentration, g-tvs/L

$\mathrm{k}_{1}^{\text {app }}$

OVL

Q

$\mathrm{R}_{\mathrm{S}}$

SOL

SOR

$\mathrm{t}$

TS total solids concentration, $\mathrm{mg} / \mathrm{L}$ or $\mathrm{mg} / \mathrm{g}$ foam

TSS total suspended solids concentration, $\mathrm{mg} / \mathrm{L}$ or $\mathrm{mg} / \mathrm{g}$-foam

TVA total volatile acid concentration, $\mathrm{mgHAc} / \mathrm{L}$

TVS total volatile solids concentration, $\mathrm{mg} / \mathrm{L}$ or $\mathrm{mg} / \mathrm{g}$-foam

$\mathrm{V}_{\text {dfed }} \quad$ daily treated influent volume, $\mathrm{L}$

$\mathrm{V}_{\text {fed }} \quad$ influent volume treated per cycle, $\mathrm{mL}$ or $\mathrm{L}$

$\mathrm{V}_{\text {reactor }}$ total volume of the reactor per cycle, $\mathrm{L}$

$\mathrm{v}_{\mathrm{S}} \quad$ liquid superficial velocity, $\mathrm{cm} / \mathrm{s}$

VS volatile solids concentration, $\mathrm{mg} / \mathrm{L}$ or $\mathrm{mg} / \mathrm{g}$-foam

VSS volatile suspended solids concentration, $\mathrm{mg} / \mathrm{L}$ or $\mathrm{mg} / \mathrm{g}$-foam

$\mathrm{X} \quad$ biomass amount, g-tvs

Symbols 


\section{Greek Letters}

\begin{tabular}{|c|c|}
\hline$\varphi$ & fixed-bed porosity, $\%$ \\
\hline$\varepsilon_{\mathrm{i}}$ & $\begin{array}{l}\text { substrate removal efficiency in the reactor } \\
\text { considering } \\
\text { concentration, } \%\end{array}$ \\
\hline$\varepsilon_{\mathrm{S}}$ & $\begin{array}{l}\text { substrate removal efficiency considering } \\
\text { filtered substrate concentration, } \%\end{array}$ \\
\hline$\varepsilon_{\mathrm{T}}$ & $\begin{array}{l}\text { substrate removal efficiency considering } \\
\text { non-filtered substrate concentration, } \%\end{array}$ \\
\hline$\mu_{\mathrm{S}}$ & $\begin{array}{l}\text { specific substrate uptake rate, } \mathrm{mgCOD} / \mathrm{g} \\
\text { tvs.h }\end{array}$ \\
\hline
\end{tabular}

\section{Abbreviations}

ASBR anaerobic sequential batch reactor

COD chemical oxygen demand

ts total solids

tvs total volatile solids

\section{REFERENCES}

Brito A.G., Rodrigues A.C. and Melo, F.L., Feasibility of a Pulsed Sequencing Batch Reactor with Anaerobic Aggregated Biomass for the Treatment of Low Strength Wastewater. Water Science Technology, 35, No. 1, 193-198 (1997).

Dague R.R., Habben C.E. and Pidaparti S.R., Initial Studies on the Anaerobic Sequencing Batch Reactor. Water Science Technology, 26, No. 911, 2429-2432 (1992).

Hirl R.J. and Irvine R.L., Reductive Dechlorination of Perchloroethylene (PCE) Using Anaerobic Sequencing Batch Biofilm Reactors (AnSBBR). $51^{\text {st }}$ Purdue Industrial Waste Conference Proceedings, Shelsea, p. 289-295 (1996).

Ndon U.J. and Dague R.R., Effects of Temperature and Hydraulic Retention Time on Anaerobic Sequencing Batch Reactor Treatment of Low-
Strength Wastewater. Water Research, 31, No. 10, 2455-2466 (1997a).

Ndon U.J. and Dague R.R.., Ambient Temperature Treatment of Low-Strength Wastewater Using Anaerobic Sequencing Batch Reactor. Biotechnology Letters, 19, No. 4, 319-323 (1997b).

Ratusznei S.M., Rodrigues J.A.D., Camargo E.M.F., Zaiat M. and Borzani, W., Feasibility of a Stirred Anaerobic Sequencing Batch Reactor Containing Immobilized Biomass for Wastewater Treatment. Bioresource Technology, 75, No. 2, 127-135 (2000).

Standard Methods for the Examination of Water and Wastewater. APHA, AWWA, WEF. American Public Health Association. 19 ${ }^{\text {th }}$ Ed., Washington. (1995)

Sung S. and Dague R.R., Laboratory Studies on Anaerobic Sequencing Batch Reactor. Water Environment Research, 67, No. 3, 294-301 (1995).

Zaiat M., Cabral A.K.A. and Foresti, E., Reator Anaeróbio Horizontal de Leito Fixo para Tratamento de Águas Residuárias: Concepção e Avaliação Preliminar de Desempenho. Revista Brasileira de Engenharia - Caderno de Engenharia Química, 11, No. 2, 33-42 (1994).

Zaiat M., Vieira L.G.T. and Foresti E., Spatial and Temporal Variations of Monitoring Performance Parameters in Horizontal-Flow Anaerobic Immobilized Sludge (HAIS) Reactor Treating Synthetic Substrate. Water Research, 31, No. 7, 1760-1766 (1997a).

Zaiat M., Vieira L.G.T. and Foresti, E., Intrinsic Kinetic Parameters of Substrate Utilization by Immobilized Anaerobic Sludge. Biotechnology and Bioengineering, 53, 220-225 (1997b).

Zaiat M., Rodrigues J.A.D., Ratusznei S.M., Camargo E.F.M. and Borzani, W., Anaerobic Sequencing Batch Reactors for Wastewater Treatment: a Developing Technology. Applied Microbiology and Biotechnology, 55, No. 1, 29-35 (2001). 